University of Nebraska - Lincoln

DigitalCommons@University of Nebraska - Lincoln

Textile Society of America Symposium

Proceedings

Textile Society of America

2020

\title{
Textile Memory in Colchane: Weavers Revitalizing the Aymara Tradition
}

Soledad Hoces de la Guardia

Follow this and additional works at: https://digitalcommons.unl.edu/tsaconf

Digitadrt of the Art and Materials Conservation Commons, Art Practice Commons, Fashion Design

Cemmens, Fiber, Textile, and Weaving Arts Commons, Fine Arts Commons, and the Museum Studies detwerkns

Logo

This Article is brought to you for free and open access by the Textile Society of America at

DigitalCommons@University of Nebraska - Lincoln. It has been accepted for inclusion in Textile Society of America

Symposium Proceedings by an authorized administrator of DigitalCommons@University of Nebraska - Lincoln. 
Published in Hidden Stories/Human Lives: Proceedings of the Textile Society of America 17th Biennial Symposium, October 15-17, 2020. https://digitalcommons.unl.edu/tsaconf/ Copyright @ 2020 Soledad Hoces de la Guardia doi: 10.32873/unl.dc.tsasp.0114

\title{
Textile Memory in Colchane: Weavers Revitalizing the Aymara Tradition
}

\author{
Soledad Hoces de la Guardia
}

The Aymara people in Colchane

The Northern Chilean territory has a dry coast, a series of ravines and some oases that allow a more extensive agriculture in the middle and the Andes mountain range that defines, in turn, two climates: a high desert in the foothills and, higher, the Andean plateau or altiplano, distinguished by steppe and grass vegetation that permits the herding of camelids and sheep.

Both regions of the far north, Arica-Parinacota and Tarapacá are home to almost all of Chile's Aymara population. ${ }^{1}$ These communities inhabit the highlands up to 4,000 meters above sea level and, practicing transhumance, they move among different ecological niches depending on the rainy periods and in search of better pasture for their animals. Starting in the 1950s, there was an increase in migratory processes from the highlands to the lowlands and currently two thirds of the Aymara people live in coastal cities such as Arica, Iquique, Alto Hospicio and some desert towns. Mining, which is very important in the area, has had a determinant effect on water use, affecting the natural balance, local herding and agriculture, and encouraging the residents to move to urban areas seeking jobs and better education for their children.

Colchane is in the Tarapacá region and it is a town that shares its name with the border with Bolivia. Located near the continental divide at 3,690 meters above sea level, it is a border crossing station. ${ }^{2}$ Due to its closeness to the neighbor country, people from this town prefer to stock up on supplies in Bolivia and there is an important exchange relationship with both sides of the border (Figure 1).

\footnotetext{
${ }^{1} 156,754$ persons, equivalent to $7.17 \%$ of the total population that self-identifies as indigenous in the country. 2017 census, Instituto Nacional de Estadísticas, Chile.

${ }^{2}$ Because of the vast length of the border, the difficult geographic and climatic conditions and the lack of resources for control, currently the community suffers from two great problems, drug trafficking and an intense influx of immigrants that has intensified during the pandemic.
} 


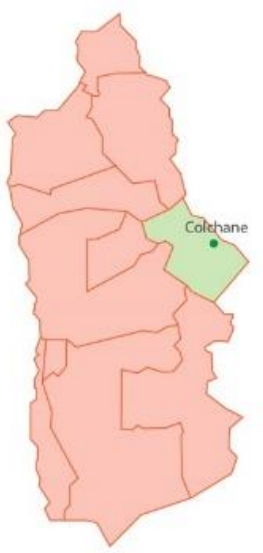

$\mathrm{b}$

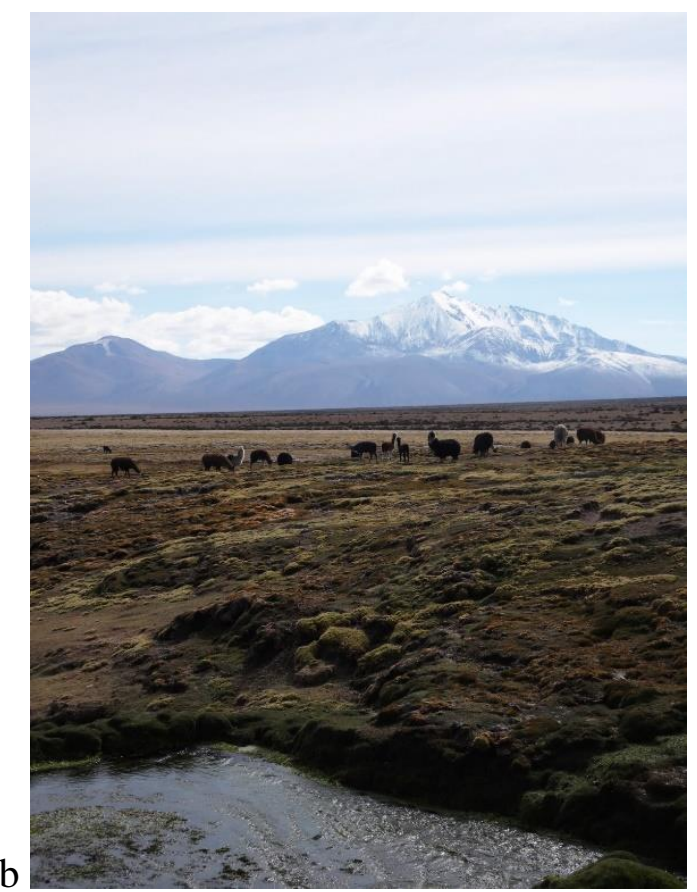

Figure 1. Geographical location in the Far North of Chile of the area where the Aymara people inhabit, sharing the border with Perú and Bolivia. a) Arica Parinacota and Tarapacá regions. The town of Colchane, place where this study was carried out, is highlighted in the image. b) Andean plateau landscape, Colchane, Parajalla area.

\section{Textile activity in Colchane}

The commune (administrative subdivision) comprises different localities such as: Enquelga, Isluga, Central Citane, Cariquina, Escapiña, Pisiga Choque, Centro and Carpa, scattered places in a wide Andean high plateau landscape that have low population density. ${ }^{3}$ This space is privileged regarding their textile crafts, for it is the place in Chile where the traditional Aymara weaving practice and culture prevail with the most fidelity and strength, especially due to its link to important herding activities. The active weavers in the commune number nearly 50 and they represent approximately $10 \%$ of contemporary Aymara weavers in Chile. ${ }^{4}$

Textiles are considered one of the most important forms of cultural expression in the Andes, due to their diverse forms, their nature as an important medium for representation and their essential role in the practices of daily life since pre-Columbian times. Current weavers are the inheritors of knowledge rigorously transmitted from generation to generation; embodying the wisdom represented in their traditional textiles, which respond to the community's functional, communicational and ritual needs. In this way, textiles as a livelihood or a trade, and textiles as an entity or a creation are one and the same, in the same way that productive and symbolic aspects always have been joined in the Aymara world, this being an essential characteristic of its textile technology and tradition (Figure 2). ${ }^{5}$

\footnotetext{
31,728 inhabitants -0.4 persons per $\mathrm{km}^{2}$.

${ }^{4}$ Personal communication by Gabriela Farías, designer, based on the registry at Artesanías de Chile, 2020.

5 Jan Van Kessel, "Tecnología aymara: un enfoque cultural," Hombre y Desierto. Una perspectiva cultural $N^{\circ} 2$. (Antofagasta: Instituto de Investigaciones Antropológicas Universidad de Antofagasta, Chile. 1988). 58-88.
} 


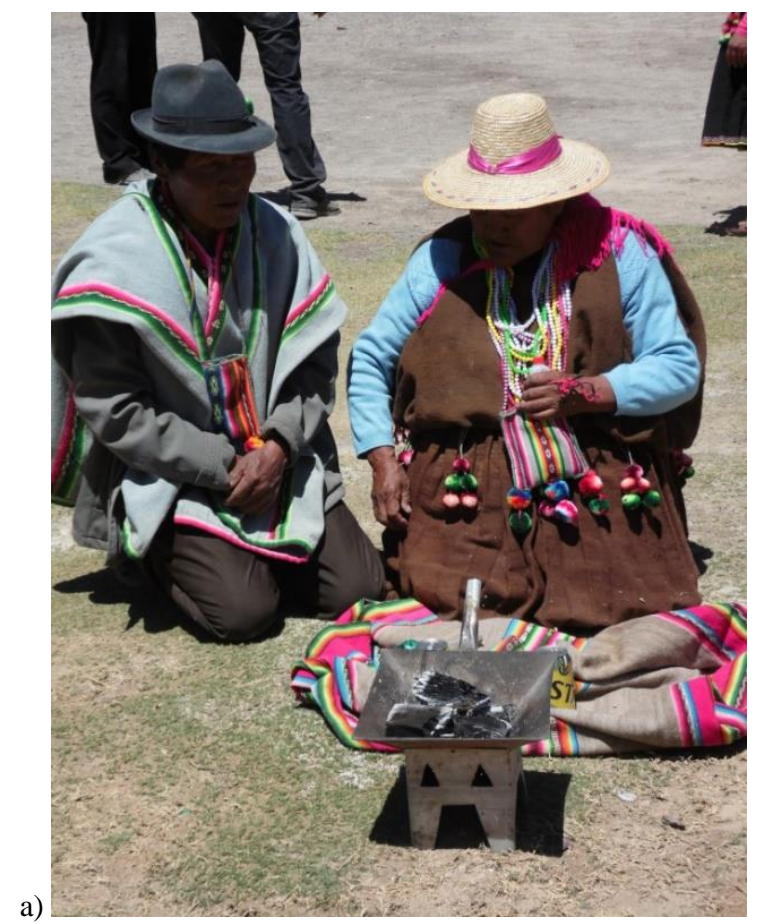

b)

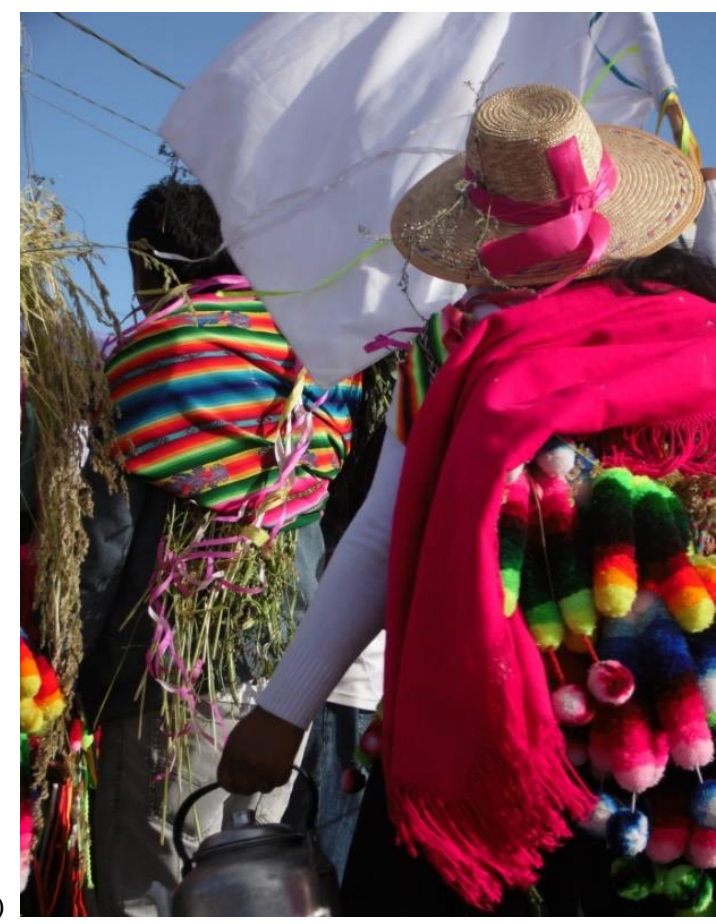

Figure 2. Traditional textiles used in rituals and celebrations. a. Ritual Mesa (table) in Isluga, October, 2014. b. Dancing during Colchane week, January 2016.

Weavings reproduce and capture forms of cultural logic, ${ }^{6,7}$ widely recognized as a medium of communication in the Andean cultures that reflects both world view and social changes experienced by their peoples. ${ }^{8}$ This valuable heritage is the receptor of diverse influences and always has been reinterpreted over time. However, it has been continuously changed, since Colonial times, by the incursion of Western culture, including new tools, different techniques and foreign design elements. Moreover, the imposition of monetary currency as a medium of exchange has altered the way of life, encouraging weavers to create products aimed to be sold in markets with different demands.

Under this pressure, the traditional weavings, heritage of a collective memory, due to being more complex and slower to execute have lost their priority in the weavers' trade. They give way to the rise of a nontraditional production, with lower costs and greater facility, in order to produce a larger volume for sale.

This has impeded transmission of textile knowledge, which has resulted in a loss of key aspects of local Aymara identity. The average age of the active weavers has risen and the younger weavers do not have the technical knowledge of their elders. An important part of their customs and traditional technical knowledge has been forgotten.

\footnotetext{
${ }^{9}$ Sophie Desrosiers, "Lógicas textiles y lógicas culturales en los Andes," Thérese Bouysse-Cassagne, ed. Saberes y memorias en los Andes. In memoriam Thierry Saignes. Institut des hautes études de l'Amérique Latine (IHEDAL) Université Paris III, Institut français d'études andines (IFEA), Paris Lima. 1997, 325-349.

${ }^{7}$ Denise Arnold, "Convertirse en persona el tejido: la terminología aymara de un cuerpo textil," Victòria Solanilla D., ed. Actas de la I Jornada Internacional sobre Textiles Precolombinos. (Barcelona: Universitat Autónoma de Barcelona. 2001), 9-28.

${ }^{8}$ Gail Silverman (1994). El tejido andino: Un libro de sabiduría. Lima: Banco Central de Reserva del Perú.
} 
Nonetheless, weaving practice, its constant reinterpretation and revitalization within the communities has been an element of continuing importance in the persistence of Andean people and their traditions. Craft activity is presented as a form of cultural resistance that recovers its strength in a time of rapid globalization, currently contributing to the revitalization and recovery of ancestral forms of knowledge. ${ }^{9}$ As a part of this process, we have seen new connections arise between artisans, artists, researchers and designers, all of them part of the text of this essay.

Recovering textile memory

Designer Gabriela Farías ${ }^{10}$ was led to explore indigenous forms of weaving in Chile as part of the development of her own designs, and in this way she got to Colchane. By 2014, this work had allowed her to build a close relationship, of mutual familiarity and confidence, with some of the artisans of the Aymar Warmi association. This is an indigenous women's association that brings together 40 artisans from Enquelga, Isluga, Colchane and Cariquina based on shared interests in textile production. In this context, they share their concerns and take measures to advocate for local crafts, promoting their participation in markets and the execution of projects that benefit their weaving activities.

This connection between the designer and the weavers allowed them to ask Gabriela for professional support for their participation in regional development projects with government financing. The public competitions for this type of project are frequently hard to navigate for those who are not familiar with the structure of their formulation and the digital submission systems, so, even those persons who naturally should apply to them do not usually present projects if they do not have some institutional or professional support.

The weavers had already begun an internal process of building awareness concerning the loss of certain techniques and some types of textiles that were no longer being woven in the community and they said they were interested in developing a project that allows them to organize in order to recover this savoir faire. To not forget "making with the hands" was presented as an urgent concern for the artisans of this community, and from this arose the project "Textile Memory."

\section{The project}

The proposed project gathered the viewpoints of professionals whose work is related to the study and recovery of endangered crafts. They propose that documentation, in all its varied forms, is essential to preserve memory and to protect the rights of the original producers.

Some related quotes from the Indian economist Amartya Sen are presented below:

"Artisans very often cannot allow themselves to keep close references and, due to that, they have never seen what their ancestors used to make. Their database is in their minds and on their fingertips. This is why there is a real risk that the drawings, designs and traditions die due to change, lack of use and even due to the death of the artisan or the family artisan group."

\footnotetext{
${ }^{9}$ Denise Arnold, Juan de Dios Yapita y Elvira Espejo (2016). Hilos sueltos: Los Andes desde el textil. $3^{\text {a }}$ edición: 23-38.

${ }^{10} \mathrm{https}: / /$ zurita-designstudio.cl/VESTIR
} 
"If the objective is just to preserve the tradition and the cultural context of a changing craft, then the best way to do so can be in a museum that reproduces the original craft and that displays it to the community as a reference to show it existed." 11

The project "Textile Memory: Reproduction and exhibition of an Aymara selection from Colchane" was executed between 2015 and 2016. Its main objective was to recover and re-learn traditional Aymara weaving techniques that were susceptible to oblivion, through the collective production of traditional textiles that would be selected, registered, conserved and managed by the Aymar Warmi association as reference material, as a creative inspiration for weavers, and as an exhibit open to the public. ${ }^{12}$

The project team included three outside professionals: Gabriela Farías, coordinator and responsible for design; Carolina Peña, organizational psychologist, and Soledad Hoces de la Guardia, professor of the UC School of Design, consultant on color and textile documentation. They worked as consultants, delivering their advice in the field and remotely in the areas of textile documentation, materials, color, work methodologies and project management.

María Choque Mamani was also part of the project team. She is an Aymara weaver that served as coordinator in the field, representing the Asociación Indígena Aymara Aymar Warmi and active partner in the execution of the project. Practical weaving workshops were led by Celinda Castro and María Mamani, both master weavers who are part of the association and were chosen by their peers for this role.

\section{Methodology}

The project was based in participative methodologies and ongoing dialogue. The first participative process was related to the project presentation, whose structure was shared with the association and particularly with the coordinator representing the association. In this process, the role of guides and facilitators was defined for the professional team, which allowed the decisions to be made by the weavers (Figure 3).
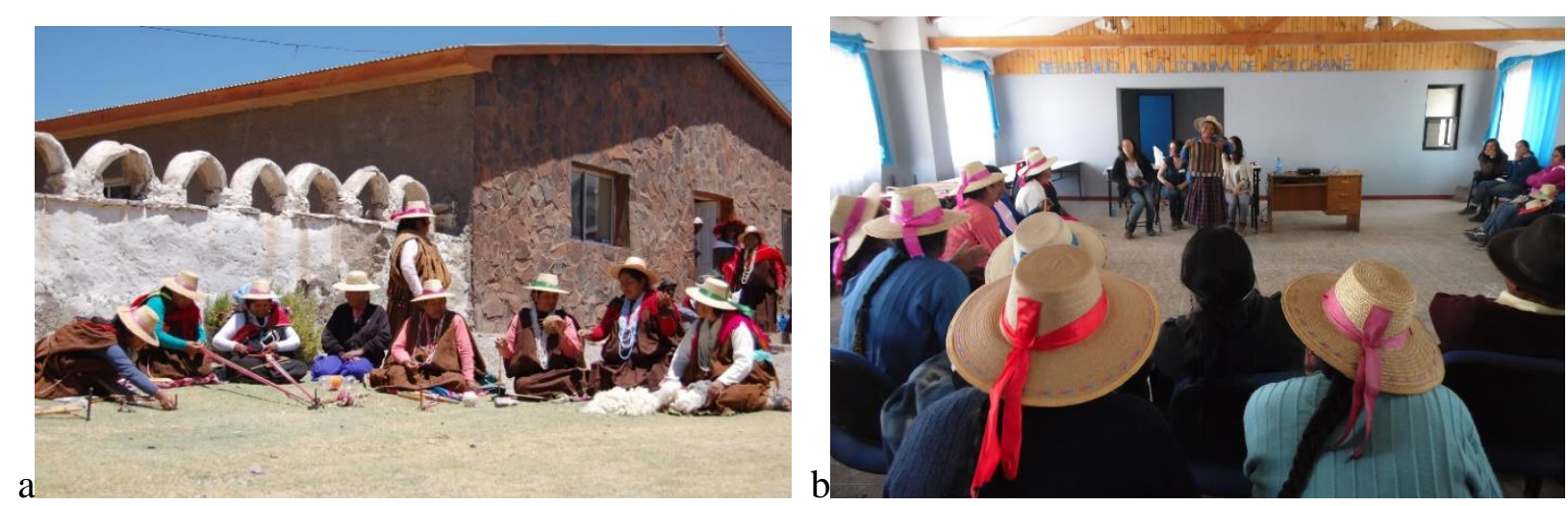

Figure 3. a) Weavers from Colchane, sharing the weaving process. b) Participative meeting in Colchane.

\footnotetext{
${ }^{11}$ Amartya Sen, "Temas teóricos de un debate práctico," Encuentro entre artesanos y diseñadores. Guía práctica. Craft Revival Trust / Artesanías de Colombia/ UNESCO (2005): 9.

${ }^{12}$ Fondart Regional grant $N^{\circ}$ 80940. Fondo Nacional de Desarrollo Cultural y las Artes, Chile.
} 
The project sought through this experience to rekindle the practice of the full weaving cycle, for in many cases the chain of production activities has been broken and the quality and mark of origin have debilitated. The purest textile tradition involves the breeding of the herds, alpaca and sheep, the spinning process, the dyeing, weaving and textile finishing. While it is clearly very difficult to recover this cycle in all cases, because there are strong economic factors and issues of access to raw materials, their revitalization was considered extremely important because, on one hand, it determines the autonomy of the weavers and in the other, it protects the authenticity of their messages.

\section{Project stages}

1. Participative inventory and classification study of the traditional types and forms of textiles. A registry was created of Aymara textile pieces from museums and private collections. They demonstrate the textile activity from this area for the past 50 years and more. ${ }^{13}$

This photographic registry was organized and shared with the weavers, making it possible to recognize, name and classify the textile forms. This showed revealing information concerning:

- The changes in the weavings, particularly in their quality of materials, use of color and finishes.

- Identification of which weavings continue in current practice which do not.

- Recognizing which of the weavers still maintain the knowledge needed to produce the most complex pieces.

2. Guided visit to the Isluga Ethnographic Textile Collection. Selection of colors and types of weavings.

In April 2015, the weavers visited the Museo Regional de Iquique in order to visit the textile collection exhibition donated by the anthropologist Verónica Cereceda. ${ }^{14}$

This exhibit, the first held after the donation, had been recently inaugurated in January 2015, and constituted a reencounter of the weavers with their own heritage. This experience was a highly significant moment in the project, as the observation of the pieces displayed was emotional and highly intimate, the weavers passing from case to case sharing their viewpoints, comments and knowledge. This visit allowed many of them to recognize textiles they had seen in their community or that had belonged to their own family (Figure 4).

\footnotetext{
13 The textile survey included the Museo Chileno de Arte Precolombino, Museo Regional de Iquique, Programa de Artesanía UC and private collections.

${ }^{14}$ Between 1970 and 1974, Verónica Cereceda carried out fieldwork in the comuna of Colchane, particularly in Isluga, and at that time she created this admirable collection, considered important documention of textiles of the region. Dr. Cereceda's studies have been foundational and a core reference in the study of Andean textiles.
} 

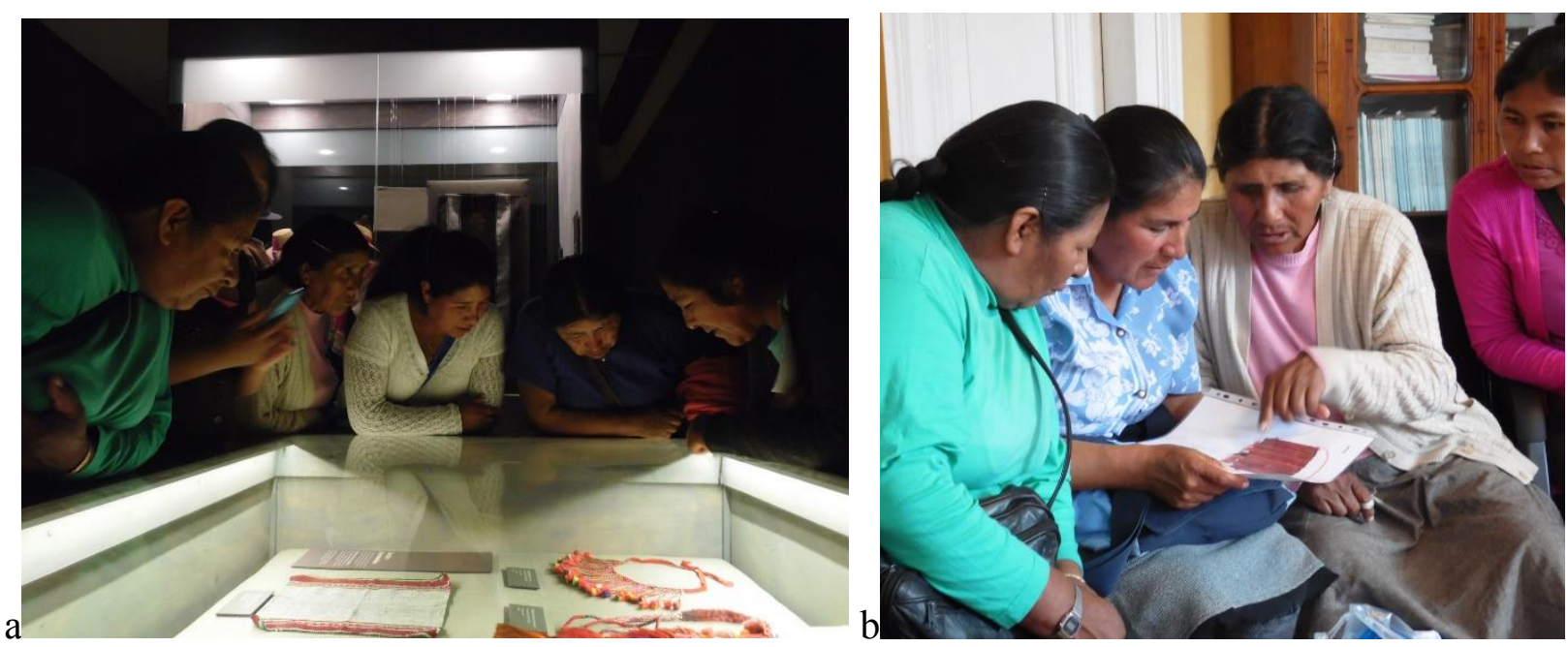

Figure 4. a) Weaver visited the exhibition of the Isluga collection in the Iquique Regional Museum. b) Weavers analyzed and selected the pieces to be woven in the project.

After this visit, the weavers together made their final selection of pieces to be reproduced, defining the collection to be made in the project. This was limited to the smaller weavings in the Aymara tradition, not including those that required a lot of material and time of execution due to the funding limits of the project.

Also, during the same gathering, they chose the color and dyeing palettes to be used in the project.

Color has been one of the aspects of Aymara textiles of this region that have seen important changes over time and also has been a foundational aspect of important studies and research processes that have greatly contributed to its understanding. ${ }^{15,16}$

Aymara weavers have always used the natural colors from the camelid fibers, called $k^{\prime} u r a$ colors, which predominate in the everyday textiles, and the dyed colors, called $p$ 'ana, which are preferentially used in festivities and rituals. In the past, all dyed colors were obtained from nature until the end of the $19^{\text {th }}$ Century, when a third type is added, colors obtained from chemical dyes. From that moment, the use of brighter colors is observed, obtained on natural fibers that, apart from the native camelid fibers, also include sheep's wool. Since the 1960s, acrylic fibers were incorporated and they added a fourth palette to the chromatic register, which was highly appreciated by the younger weavers due to its great intensity. Their interpretation of this new form of chromatic expression is an important part of the message contained in the areas of narrow stripes with meticulous color gradations that pass from one dyelot to another. These are called $k$ 'isas (Figure 6). ${ }^{17,18}$

\footnotetext{
15 Verónica Cereceda, "Semiología de los textiles andinos: Las Talegas de Isluga,” Revista Chungara Vol. 42 No. 1 (Arica: Universidad de Tarapacá, 2010): 81-198.

${ }^{16}$ Penelope P. Dransart, "Continuidad y Cambio en la producción textil aymara," Hombre y Desierto, una perspectiva cultural. Antofagasta, Vol. 2, (1988), 41-57.

${ }^{17}$ Dina Medvinsky. Las fajas de isluga. Thesis to obtain the designer degree. Design School PUC.1977.

${ }^{18}$ Penelope Dransart, "The sounds and tastes of colours: hue and saturation in Isluga textiles," Nuevo Mundo

Mundos Nuevos. Textiles amerindios. Diferentes perspectivas sobre los colores. 2016.

https://doi.org/10.4000/nuevomundo.69188
} 


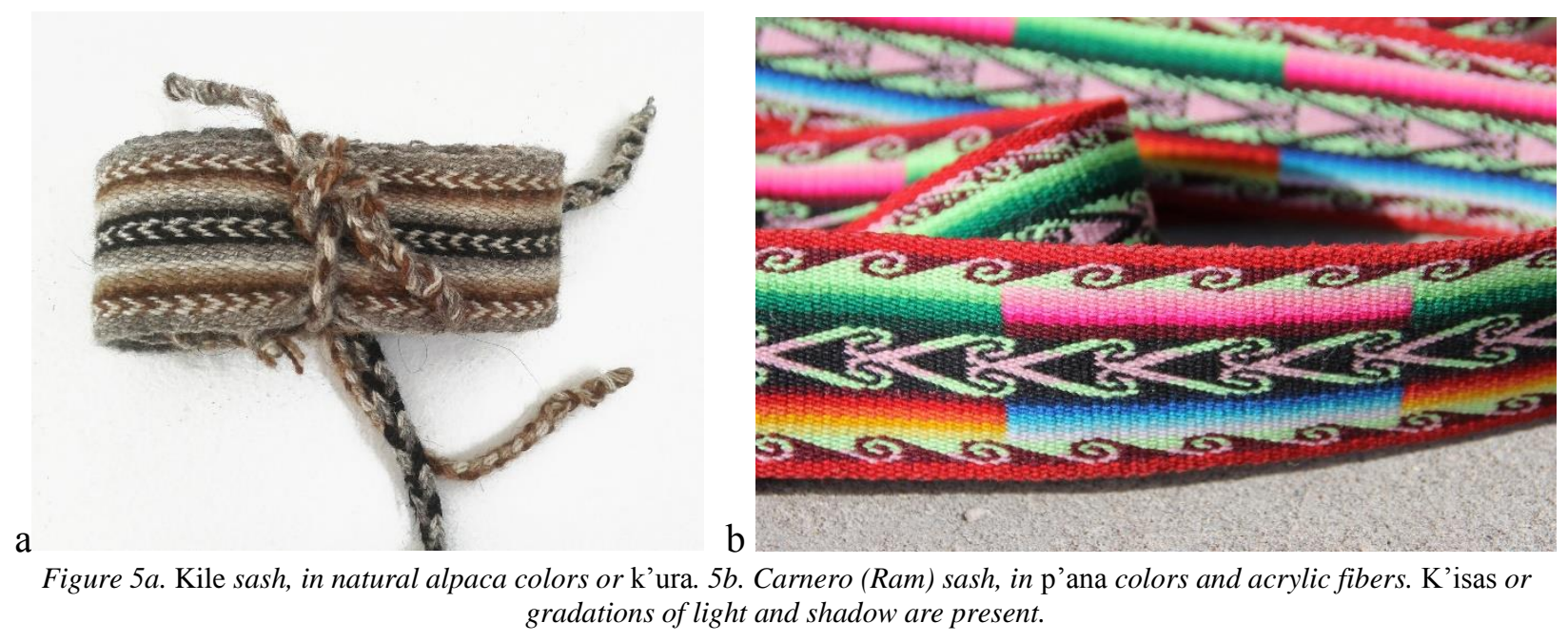

The weavers expressed their interest in adding a fifth palette developed in a research project they had become familiar with thanks to Aymara weavers from Arica -a northern city- that had used it. This palette reproduced colors from pre-Columbian textiles using chemical dyes, replicating with accuracy the colors obtained originally using natural dyes. ${ }^{19}$

This responds partly to the difficulties the weavers face in reproducing colors that were formerly achieved by natural dyeing and that currently cannot be obtained due to loss of the knowledge of the techniques, and also due to the extinction of the vegetal resources that had produced the colors or the ecological risk posed by their massive extraction today.

3. Purchase and distribution of raw material for creating the yarns.

As stated above, the project took into consideration the autonomy implied by yarn production by the weavers themselves. For those who didn't have their own herd, a supply was ensured through the buying and distribution of alpaca fiber so everyone could spin their own materials. In both cases, the costs of the fiber were covered with the project funds.

\section{Dyeing workshops.}

In a third phase of the project, workshops on dye practices were scheduled to reproduce the selected color to be obtained using chemical dyes. 34 colors were obtained and reproduced. 17 of them already used in contemporary weavings of the community and the other 17 from the preColumbian color chart, according to those selected by the weavers (Figure 6).

\footnotetext{
${ }^{19}$ Soledad Hoces de la Guardia, Paulina Brugnoli, and Paulina Jélvez, Registro cromático en textiles de la cultura Arica en el Período Intermedio Tardío: Caso inkuñas. In Boletín del Museo Chileno de Arte Precolombino. Vol. 16, $N^{\circ}$ 1. 2011. 67-9. https://boletinmuseoprecolombino.cl/wp/wp-content/uploads/2015/12/bol16-1-05.pdf
} 

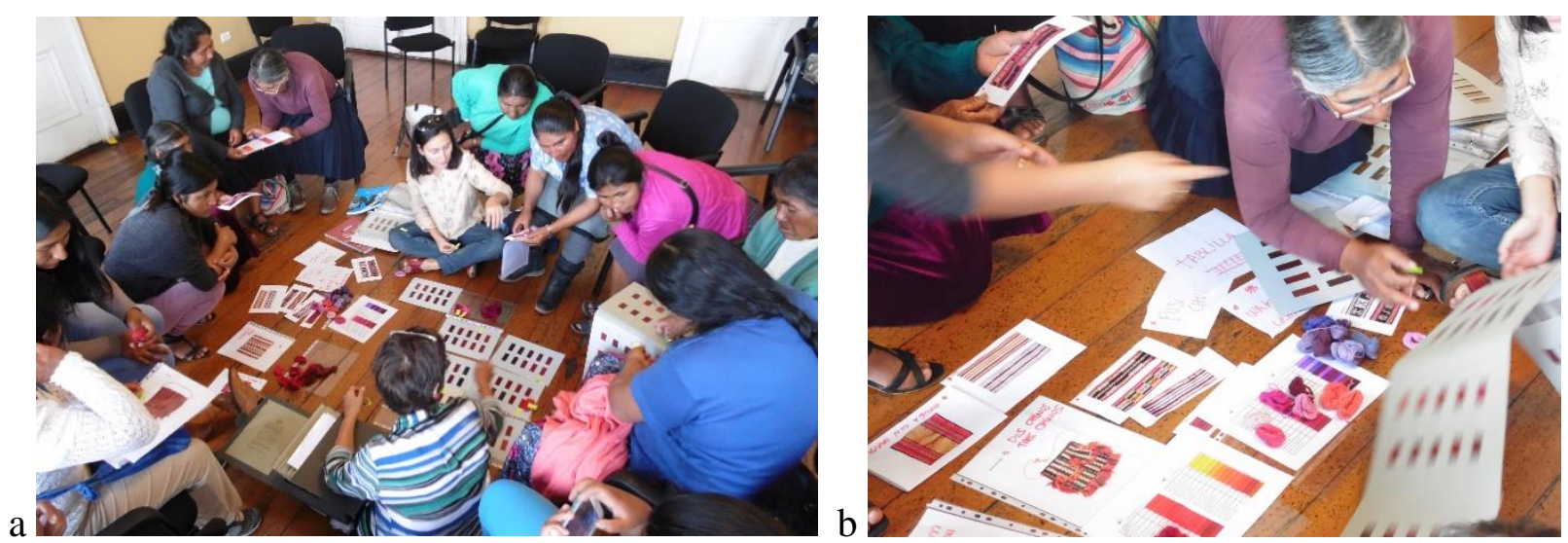

Figure 6. a) Weavers review and select the colors from the different chemical dye charts. $b$ ) Selected colors are compared with the pieces chosen to be reproduced.

Dye selection also considered the use of Azo-free dyes (non-carcinogenic) and a dye process that reduced the collateral damage as much as possible, concerning water use and metallic mordants. A sufficient quantity of aniline dyes was acquired to meet the need of the project and to assure its continuation for a considerable time. Weavers distributed the dyed materials and later they continued to meet according to the needs of their respective projects (Figure 7).
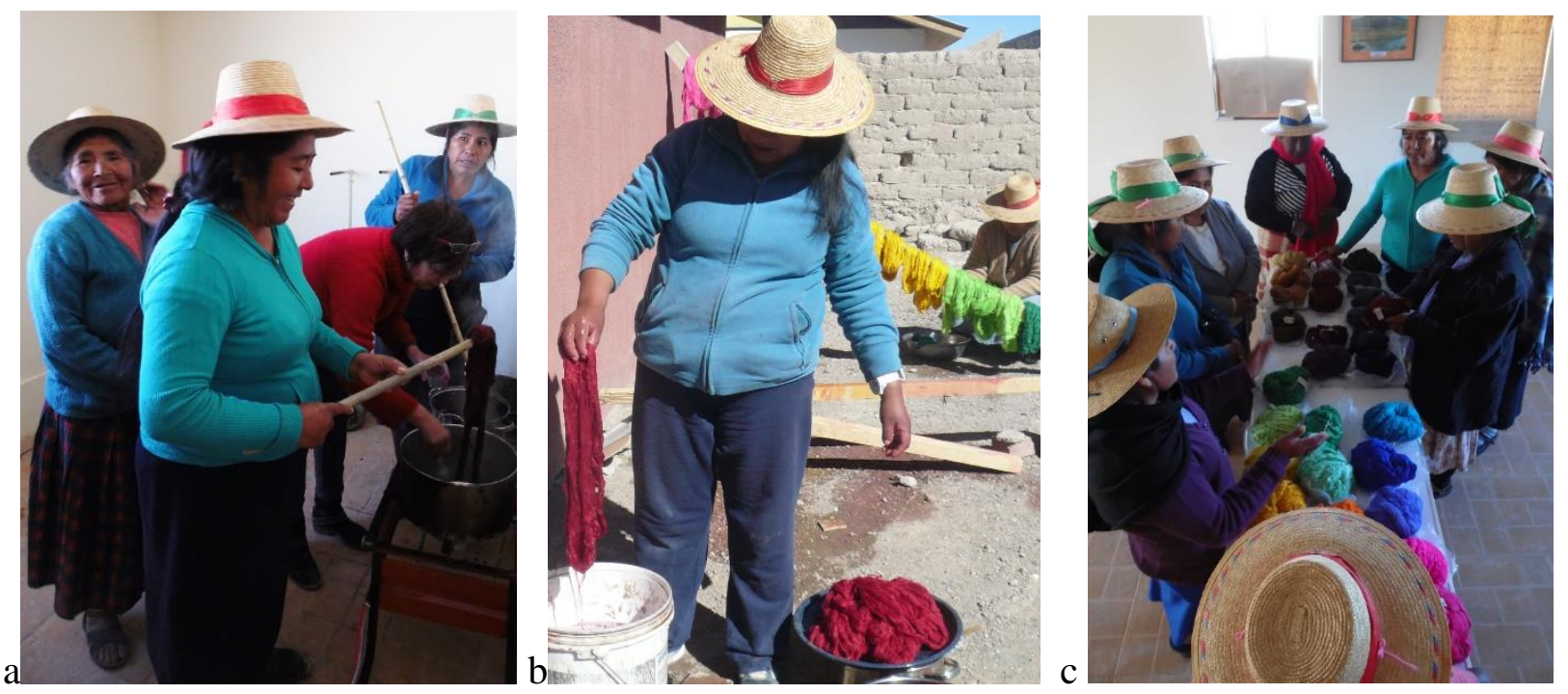

Figure 7. a) Dye workshop. b) Color reproductions made by artisans. c) Review of the colors obtained.

5. Weaving of the chosen forms of textiles.

Weaving workshops were led by expert weavers from the same community chosen in a meeting by the participant artisans. Those chosen were those considered as teachers, recognizing their capabilities in the mastery of weaving techniques, as well as their ability to interact with the others. In this way, Celinda Castro and María Mamani were chosen. They organized the working groups according to their interests and the areas where the weavers lived. Activities were carried out mainly in the community center administrated by the association in Colchane, but there were also some activities in the nearby town of Enquelga, where one of the teachers has her home. 
For this organizational process, weavers had to sign up according to their interest in taking on and reproducing a particular piece. This was done using a survey that had three questions based on a photographic dossier of the pieces selected: Which of these pieces is unfamiliar to you? Which of these do you not know how to weave? Which of these would you like to weave?

The analysis of this information made it possible to perceive the preferences and concerns held in common by many of the weavers, while making evident losses or gaps in their savoir faire. In this selection process, three pieces stand out in which their more elaborate design or more complex techniques had been forgotten: warp resist dyeing (talega bag 4), the mallku vistalla bag types 1 and 2 and the Quimsa churu band with three-layered warping (Figure 8).

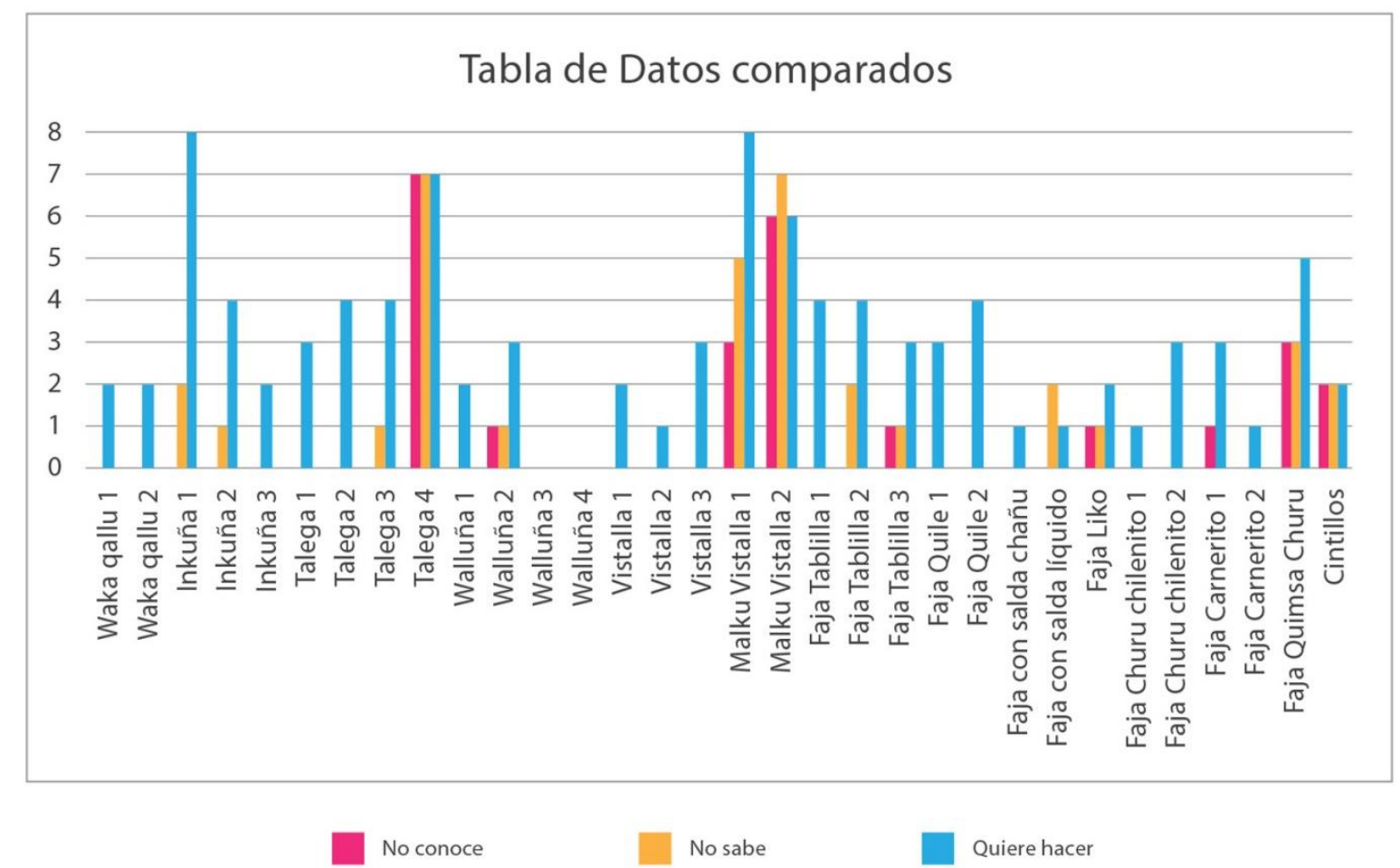

Figure 8. Comparing the data from asking weavers to: Choose the pieces you do not know; choose the pieces you do not know how to weave; choose the pieces you would like to weave. Pieces which are more complex are most often named in answering the three questions.

Weaving was done on traditional Andean looms: backstrap looms and four-stake looms. The artisans made several types of bags, bands and pieces that serve as ornamental elements of clothing.

This activity was completely autonomous. Weavers worked for 3 months learning and collaboratively developing the different pieces they had selected and at the end of this period, they presented the first group woven. Subsequently the process continued, and the 21 weavers who participated in the project were able to create 60 pieces in all (Figure 9). 

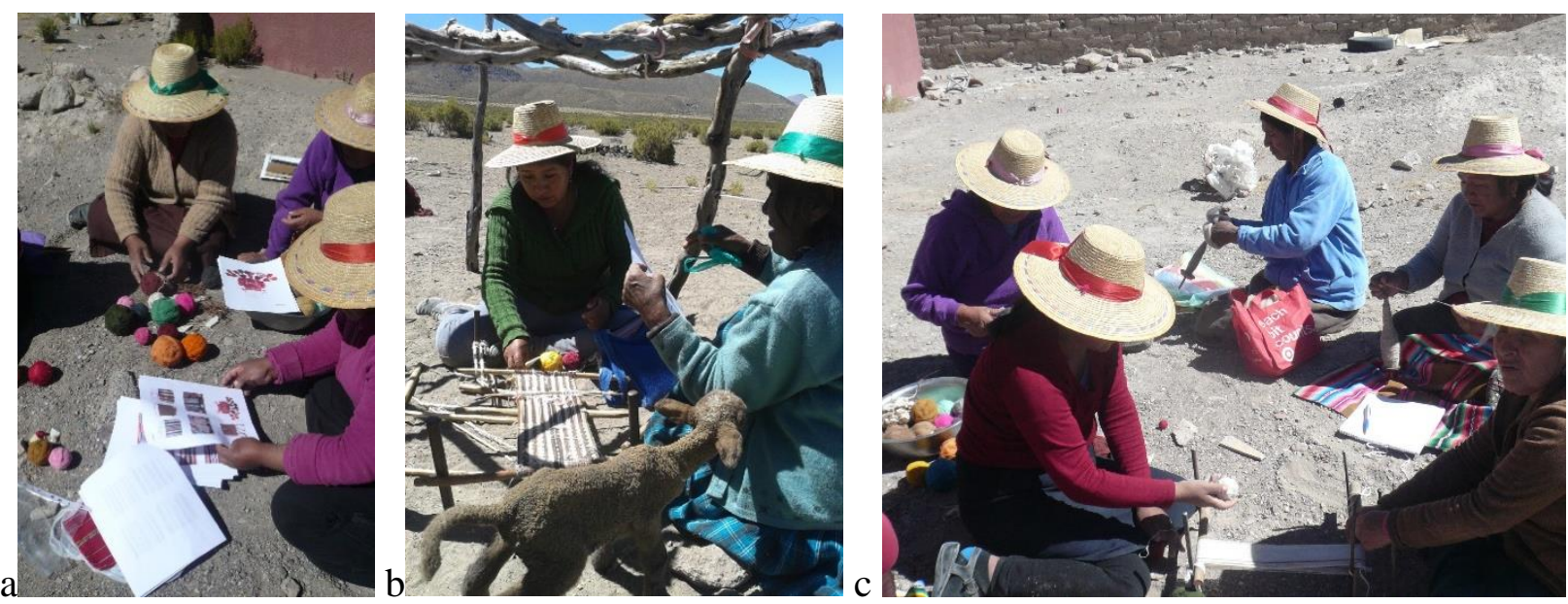

Figure $9 a, b$ and $c$. Workshops and exchange of experience among the weavers in order to learn and reproduce pieces from the collection.

\section{Textile archive exhibition}

The total of 60 woven pieces for the Project included 18 different types, so for this reason there were different versions of the same piece. This led to the need for a selection process, which was also carried out by the weavers. The final exhibit consisted of 20 pieces that were outstanding due to the quality of the yarns, their colors and excellent levels of skill, at the same time representative of the project as it included 15 of the participant weavers (Figure 10).
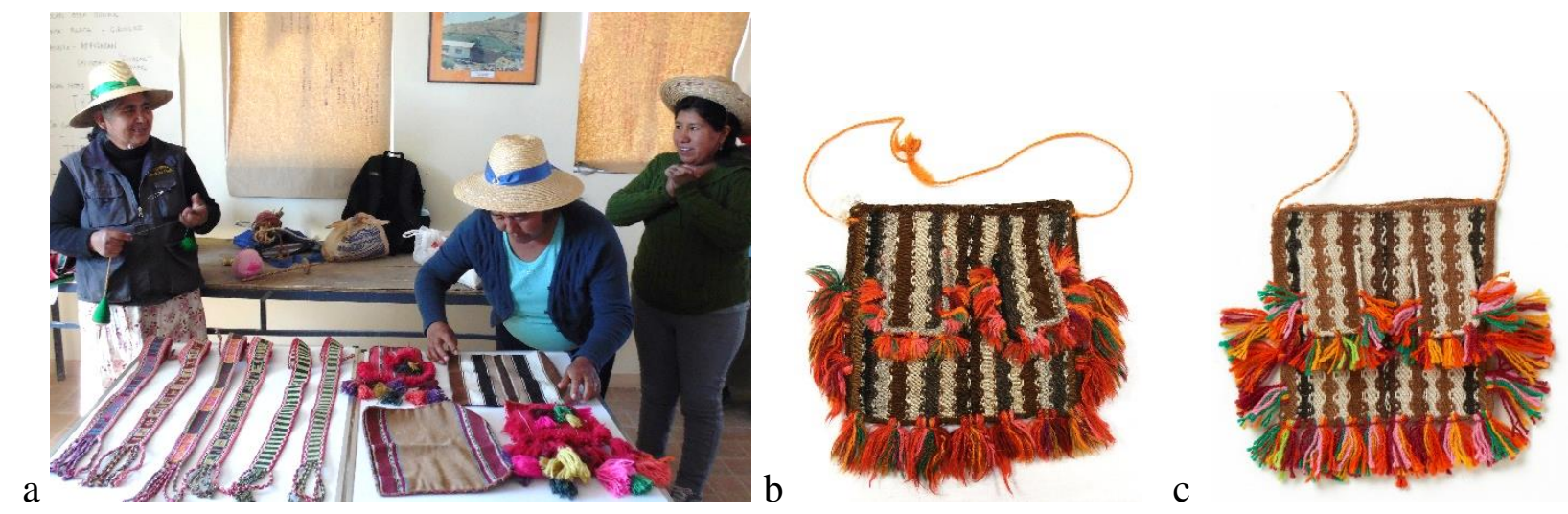

Figure 10. a) Weavers select the pieces for the exhibition. b) Reference piece 2276, Museo Chileno de Arte Precolombino. c) Chuspa bag reproduction, Mallqu wistaya, woven by María Mamani.

At the same time, in Santiago, a piece of furniture was designed and constructed that would create adequate conditions for the conservation of the pieces. It had to be sufficiently compact to potentially be moved while also having the visual qualities of a display cabinet. This required the functionality of being opened for exhibition and closed for storage of the pieces. This project was designed and constructed by architect María José Peña. ${ }^{20}$

${ }^{20}$ www.tallercolectivo.com 
The weavings each were documented with a brief description and identification cards made for their exhibition. As complementary material, a high-quality photographic registry was made in order to be able to produce graphic materials such as posters and postcards for outreach and advertisement of the project and its results.

The inauguration of the exhibit was held in the school library in January 2016, during the same week as the annual celebration and festival in Colchane. The ceremony began with a gratitude challa and mesa (offering and ritual table) officiated by an Aymara yatiri (ritual specialist) along with the weavers and the authorities of the comuna, and was open to the community. On that occasion, participants shared their experiences and gratitude was expressed to all those who were part of the project (Figure 11).
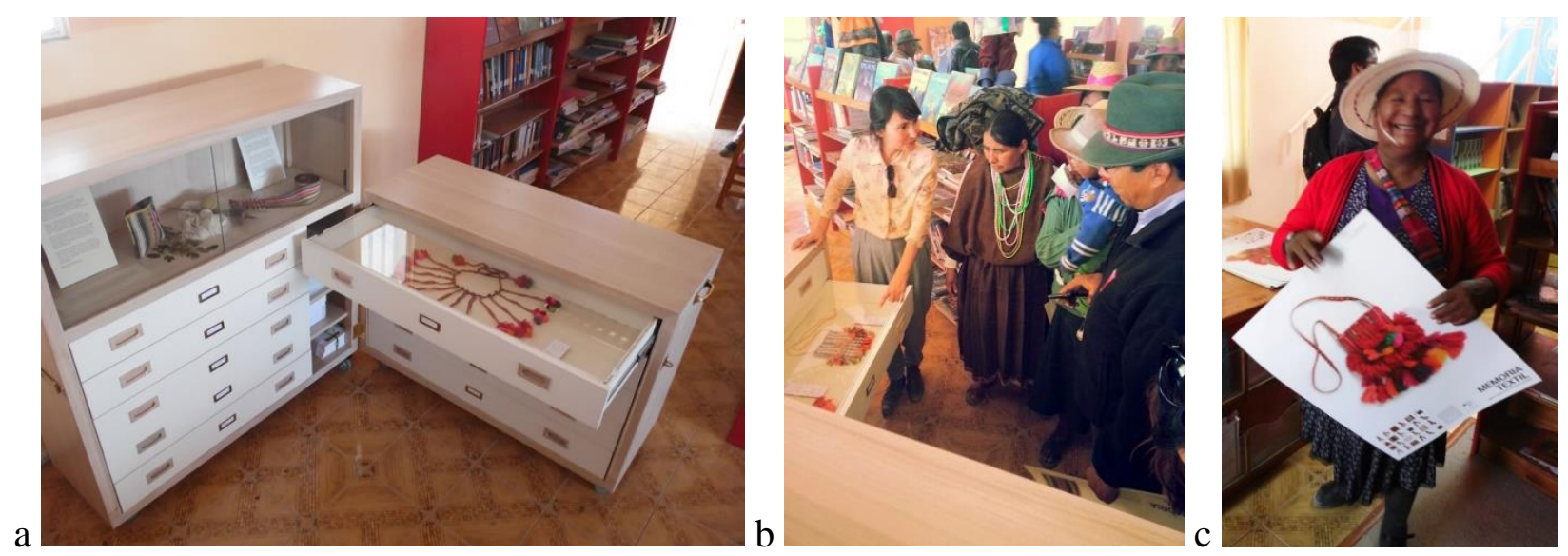

Figure 11. a) Textile archive furniture. b) Weavers and visitors meet the exhibition during the inauguration. c) Weavers celebrate the achievement of the project.

\section{$\underline{\text { Some thoughts }}$}

The project facilitated connections among different social spaces and involved many people, inspiring a response that has demonstrated positive results that can be seen today.

The participation of the professionals was restricted to the role of facilitators, understanding that that the solutions must come from the weavers so the results would be considered valid within the community. The research that has been carried out on Andean textile heritage within academic spaces can be justified and become more valuable when its results can be delivered to the heirs of these forms of knowledge in order to recreate and revitalize their own work.

"Textile Memory" was born as an effort to find a balance between the production aspects and the symbolic aspects of this kind of craft through creating a collection that would foster both documentation and recognition of this textile heritage and its creative process, making available reference materials for those who observe with their eyes and their hands in order to recreate, revitalize, study and learn about these weavings. The project, which basically consisted of the collective design of a salvage collection, made it possible to generate new interactions within the group of weavers, leading to the recovery of their confidence. Moreover, it elevated the peer recognition of local master weavers who were in charge of the transmission of knowledge that went beyond the technical sphere and their role as weavers, since together with weaving, the raison d'être of these textiles was also recovered and its context documented. 
The exhibit has become a local reference collection and currently is custodied by one of the weavers as it continues to be consulted by the artisans, who sometimes borrow the weavings, which like books from a library are lent to them for a certain time so they can act as a guide in a continuous learning process. The organization of this group of textiles has encouraged the local authorities to consider the possibility of recovering some textiles that have become part of museum collections elsewhere in order to have a more substantial exhibit in Colchane.

Another significant consequence of this experience has been the active participation of weavers, both men and women, from this comuna in the national competition and recognition called Sello Indígena since 2016 until today. Eight woven pieces have received awards during this time. Two of them (2017 and 2020) represent the skill set and types of textiles recovered in this project. ${ }^{21}$

\section{Acknowledgements}

I would like to express my recognition to the weavers who participated in the project, especially María Choque, Celinda Castro and María Mamani, who guided the activities in the commune and to each one of those who trusted and dreamed in weaving: Luisa Castro, Marina Castro, Rogelia Castro, Celia Challapa, Isabel Challapa, Magrina Challapa, María Challapa, Julia Choque, Petronila Choque, Juana Flores, Filomena García, Alberta Gómez, Primitiva Gómez, Adriana Mamani, Idalia Mamani, Juana Mamani, Soria Mamani and Marcelina Mamani.

My deepest gratitude to my partners Gabriela Farías and Carolina Peña, who never imagined the gift that it was for my mind and spirit to be invited to and participate in this project.

My recognition to TSA and each of the participants in the session "Dialogues between archaeological, historical and contemporary textiles in the Andes", and especially to Ann Peters who brought us together and organized meetings that provided mutual support during the 2020 pandemic.

\section{Bibliography}

Arnold, Denise. Juan de Dios Yapita y Elvira Espejo (2016). Hilos sueltos: Los Andes desde el textil. $3^{\text {a }}$ edición: 23-38.

Arnold, Denise. "Convertirse en persona el tejido: la terminología aymara de un cuerpo textil." Victòria Solanilla D., ed. Actas de la I Jornada Internacional sobre Textiles Precolombinos. (Barcelona: Universitat Autónoma de Barcelona. 2001), 9-28.

Cereceda, Verónica. "Semiología de los textiles andinos: Las Talegas de Isluga." Revista Chungara Vol. 42 No. 1 (Arica: Universidad de Tarapacá, 2010): 81-198.

Desrosiers, Sophie. "Lógicas textiles y lógicas culturales en los Andes." Thérese BouysseCassagne, ed. Saberes y memorias en los Andes. In memoriam Thierry Saignes. Institut des

\footnotetext{
${ }^{21}$ https://www.cultura.gob.cl/sello-artesania-indigena/
} 
hautes études de l'Amérique Latine (IHEDAL) Université Paris III, Institut français d'études andines (IFEA), Paris Lima. 1997, 325-349.

Dransart, Penelope. "The sounds and tastes of colours: hue and saturation in Isluga textiles." Nuevo Mundo Mundos Nuevos. Textiles amerindios. Diferentes perspectivas sobre los colores. 2016. https://doi.org/10.4000/nuevomundo.69188

Dransart, Penelope P. "Continuidad y Cambio en la producción textil aymara," Hombre y Desierto, una perspectiva cultural. Antofagasta, Vol. 2, (1988), 41-57.

Hoces de la Guardia, Soledad, Paulina Brugnoli, and Paulina Jélvez. Registro cromático en textiles de la cultura Arica en el Período Intermedio Tardío: Caso inkuñas. In Boletín del Museo Chileno de Arte Precolombino. Vol. 16, $N^{\circ}$ 1. 2011. 67-9. https://boletinmuseoprecolombino.cl/wp/wp-content/uploads/2015/12/bol16-1-05.pdf

Medvinsky, Dina. Las fajas de isluga. Thesis to obtain the designer degree. Design School PUC.1977.

Sen, Amartya. "Temas teóricos de un debate práctico." In Encuentro entre artesanos y diseñadores. Guía práctica. Craft Revival Trust / Artesanías de Colombia/ UNESCO (2005): 9.

Silverman, Gail. El tejido andino: Un libro de sabiduría. Lima: Banco Central de Reserva del Perú, 1994.

Van Kessel, Jan. "Tecnología aymara: un enfoque cultural.” Hombre y Desierto. Una perspectiva cultural $N^{\circ} 2$. (Antofagasta: Instituto de Investigaciones Antropológicas Universidad de Antofagasta, Chile. 1988). 58-88. 